\title{
Extraction of Non-Edible Forestry Seed Oil in the Utilization as a Blend Fuel: Millettia Pinnata (Honge, Karanja)
}

\author{
Karabasappa H Byadgi ${ }^{1}$, Mohan $\mathbf{N} \mathbf{R}^{2}$ and Madhukumar $\mathbf{R}^{3, *}$ \\ ${ }^{1}$ Department of Chemistry, KLE Society’s Gudleppa Hallikeri College Haveri - 581 110, Karnataka, India. \\ ${ }^{2}$ Assistant Adviser, National Assessment and Accreditation Council (NAAC), \\ Nagarbhavi, Bangalore - 560072, Karnataka, India \\ 3*Department of Physics, RTES Arts Science and Commerce Degree College, Ranebennur-581115, Karnataka, India
}

\begin{abstract}
Energy is the basic requirement for the existence of human being in today's digital world. Diesel engines are widely used in light, medium and heavy-duty vehicles and power generation in heavy machinery, because of higher thermal efficiency and the ability for lean operation. Further, the lean burn capability helps to lower the carbon monoxide (CO) and Hydro carbon (HC) emissions compared to those of a spark ignition (SI) engine. The world energy stimulated the researchers to look for new sources of fuel, which must be renewable, locally available and environmentally benign. In this regard, the significance of biodiesel as technically and commercially viable alternative to fossil-diesel has led to intense research in the field. Biodiesel is made from different feedstock depending on the availability. This paper Extraction of non-edible forestry seed oil in the utilization as a Blend fuel. Milletia pinnata is a species of tree in the pea family, Fabaceae, that is native to southern Asia. It is often known by the synonym Pongamia pinnata as it was moved to the genus Millettia only recently. Common names include Indian Beech Tree, Honge Tree, Pongam Tree. The main advantage of biodiesel is that it potentially reduces the key pollutants, carbon monoxide, unburnt hydrocarbons and particulate matters. However, many further researches need to be carried out to understand the relationship between the type of biodiesel feedstock and performance and emission
\end{abstract}

Keywords: Cylinder block, V8 engine, design, analysis.

\section{INTRODUCTION}

The first studies on using vegetable oil in diesel engines were led by Gaupp in 1937 and focused on how the physical properties of various vegetable oils, such as viscosity, Pour point or iodine value, affected diesel engines. The impacts of vegetable oil contaminants on diesel engines (such as water or phosphorus) were not a matter of concern at that time. In 1982, during the International Conference on Plant and Vegetable Oils as Fuels, Pryde proposed a first tentative SVO standard. In his study, Pryde found that SVOs did not meet the ASTM 975 specifications for Fuel Oil No. 2. He reported that some analytical methods were not suited to SVO, especially those used for measuring the flash point, $90 \%$ distillation temperature and cetane number. He recommended working on vegetable oil modifications to successfully give them physico-chemical properties compliant with standard No.2 (dilution, transesterification, preheating, microemulsions) rather than adapting standard No. 2 to SVOs. However, he suggested a tentative standard, with some limit values for several specifications, but also specifying: "vegetable oils must be recognized as experimental fuels. Therefore the suggested specifications for vegetable oils merely serve as a means for determining the quality or even identity of the experimental fuels and do not serve as specifications for fuel use". Because of the low petroleum oil prices in the 1980s and then the major interest of the United States in biodiesel, the work initiated by Pryde was never carried on. The Honge Tree is well-adapted to arid zones and has many traditional uses. It is often used for landscaping purposes as a windbreak or for shade due to the large canopy and showy fragrant flowers. The bark can be used to make twine or rope and it also yields a black gum that has historically been used to treat wounds caused by poisonous fish. The flowers are used by gardeners as compost for plants requiring rich nutrients. Although all parts of the plant are toxic and will induce nausea and vomiting if eaten, the fruits and sprouts, along with the seeds, are used in many traditional remedies. Juices from the plant, as well as the oil, are antiseptic and resistant to pests. In addition M. pinnata has the rare property of producing seeds of $25-40 \%$ lipid content of which nearly half is oleic acid. Oil made from the seeds, known as honge oil, is an important asset of this tree and has been used as lamp oil, in soap making, and as a lubricant for thousands of years [1-3]. 


\section{International Advanced Research Journal in Science, Engineering and Technology}

Vol. 8, Issue 6, June 2021

DOI: $10.17148 / I A R J S E T .2021 .8620$

The main evolutions concern the phosphorus content, whose limit dropped from 30 to 12 ppm in pre-standard DIN V 51605. Special attention was paid to phosphorus not only because of the formation of deposits that clog injectors and valves, and foul the walls of the combustion chamber, but also because phosphorus is a poison to catalysts used in exhaust mufflers to oxidize unburnt residues. Moreover, the catalysts used in modern diesel engines can be deactivated by earth alkali metals, such as $\mathrm{Ca}$ and $\mathrm{Mg}$, which became important parameters to control in SVOs, and the commission has been working on $\mathrm{Na}$ and $\mathrm{K}$ specifications in the last few years.

\subsection{Biodiesel Goes Worldwide}

Pioneering work in Europe and South Africa by researchers such as Martin Mittelbach furthered development of the biodiesel fuel industry in the early 1990s, with the U.S. industry coming on more slowly, due to lower prices for petroleum diesel. Pacific Biodiesel became one of the first biodiesel plants in the United States in 1996, establishing a biodiesel production operation to recycle used cooking oil into biodiesel on the island Maui in Hawaii. The biodiesel industry became a household name in the U.S. after the terrorist attacks of 9/11/2001 resulted in historically high oil prices and an increased awareness of energy security. As of 2005, worldwide biodiesel production had reached 1.1 billion gallons, with most fuel being produced in the European Union, although biodiesel projects worldwide have been on the rise due to rising crude oil prices and concerns over global warming [4].

\subsection{The Future of Biodiesel Fuel}

Due to its clean emissions profile, ease of use, and many other benefits, biodiesel is quickly becoming one of the fastest growing alternative fuels in the world. With minimal subsidy biodiesel is cost competitive with petroleum diesel, and millions of users have found and enjoyed the benefits of the fuel. The future of biodiesel lies in the world's ability to produce renewable feed stocks such as vegetable oils and fats to keep the cost of biodiesel competitive with petroleum, without supplanting land necessary for food production, or destroying natural ecosystems in the process. Creating biodiesel in a sustainable manner will allow this clean, renewable, and cost effective fuel to help ease the world through increasing shortages of petroleum, while providing economic and environmental benefits well into the 21 st century.

\subsection{An Approach to replace diesel by unmodified vegetable oils, as diesel fuel extenders}

Many studies have been done at the University of Idaho and elsewhere involving

vegetable oils as a primary source of energy. Particularly, during the early 1980's, studies were completed that tested the possibility of using unmodified vegetable oils as a replacement for diesel fuel. There is no question that vegetable oil can be placed in the tank of a diesel powered vehicle and the engine will continue to run and deliver acceptable performance. Some vegetable oils, such as rapeseed oil, have very high viscosity and thus may starve the engine for fuel when operated at 100 percent. Most studies show that power and fuel economy, when compared to operation on diesel, are proportional to the reduced heat of combustion of the vegetable oil fuel [5].

\subsection{Non-Edible Oil Resources in India:}

Vegetable oils have considerable potential to be considered as appropriate alternate fuel as they posses fuel properties similar to that of diesel. Moreover, review of literature revealed that with the use of vegetable oils, as fuel in diesel engines is beneficial because, these are non-toxic, biodegradable, eco-friendly and renewable in nature and the use of vegetable oils in diesel engine reduces emissions. India has rich and abundant forest resources with wide range of plants and oil seeds. There are more than 300 different species of trees available in India. The oils can be obtained from many oil seeds. Based on the application or use of vegetable oils, the vegetable oils are classified in to two types. Namely edible and non-edible oils. Economics of the biodiesel production process can be improved, if non-edible oils are used. Because, in Indian context, due to growing population there always exists great demand for edible oil consumption and hence too expensive for the engine application. Therefore only non-edible vegetable oils can be seriously considered as fuel for CI engine. But, in European countries and USA, they have mainly concentrated on suffola, sunflower, peanut oils etc as alternate fuels for CI engines and which are edible in nature. As mentioned earlier, India has abundant forest resources with wide range of plants and oil seeds. Therefore, non-edible vegetable oils available in our country. If we can harness these oils to make synthetic diesel our dependency on imported crude oil, if not totally eliminated can be reduced. Therefore keeping in view of the sociological and economical aspects, attempts on the use only of non-edible vegetable oils have become more relevant [6].

\section{Biological diesel}

Biodiesel is the name of a clean burning alternative fuel, produced from domestic, renewable resources. Biodiesel contains no petroleum, but it can be blended at any level with petroleum diesel to create a biodiesel blend. It can be used in compression-ignition (diesel) engines with little or no modifications. Biodiesel is simple to use, biodegradable, nontoxic, and essentially free of sulphur and aromatics. 


\section{International Advanced Research Journal in Science, Engineering and Technology}

Vol. 8, Issue 6, June 2021

DOI: $10.17148 /$ IARJSET.2021.8620

\section{Non-edible forestry seed oil}

Its properties are determined by the individual 'fatty acid' chains. Rapeseed oil, for example, may be composed of different combinations of about 6 different fatty acids and each one of these creates a unique molecule, with unique properties. Some waste oil contains 'free fatty acid', which Non-edible forestry seed oil comes in very many shapes and sizes, with varying properties. The most important consideration is melting point. The actual non-edible forestry seed oil molecule is composed of three long carbon chains on a glycerol 'backbone' and is a result of water in fried food reacting with the triglyceride to split it up into it's four components. Waste oil also contains varying amounts of animal and fish oils which may be solid at room temperature in their natural state. As a breast of chicken, for example, is fried, oil diffuses out of the chicken and is replaced by oil from the fryer and as more and more chicken is fried, the concentration of chicken oil increases, thickening the oil until it may become solid.

There are many different types of non-edible forestry seed oil and each one has unique properties. The best one for use as a fuel is undoubtedly rapeseed oil as it is relatively thin, cheap to produce and easy to get hold of. A second best would be sunflower oil. If you go into a supermarket in the UK, rapeseed oil is the stuff in the cheap plastic bottles which sometimes has little yellow flowers on it [7-8].

\section{Ratio of Non-edible forestry seed oil to Diesel}

The following is taken from this source. How much oil should you use? Start with a light blend, and increase each time you refill. That way, if you notice your car sputtering, you know you've hit the limit and should use less next time, and you can top up with regular diesel to thin the mixture back down.

- $\quad$ A $20 \%$ oil oil blend will work for everyone. It meets your personal part of our Kyoto commitment, and there should be no noticeable difference in how your car drives. The exhaust stops smelling like a taxi and starts smelling like a donut fryer. It is pleasant and a real talking point. You should notice the slight smoothness improvement around now.

- At $50 \%$ oil in $50 \%$ diesel, $50 \%$ is a good running blend for the rest of the year with less emission.

- $\quad 75 \%$ - one part oil to $25 \%$ parts regular diesel - is the heaviest mix one would recommend for the British winter, unless you've got a frost-free garage. This level of blend still starts even on cold, frosty mornings.

\section{EXPERIMENTAL METHODS OR METHODOLOGY}

$100 \mathrm{gm}$ of the selected seeds were crushed \& loaded in sohexelet apparatus. It was continuously extracted for the period of $24 \mathrm{hrs}$. Solvent was dried over anhydrous sodium sulphate \& evaporated on rotator flash evaporator. Oil was recovered.

\subsection{Solid and semi solid samples}

Soften sample if necessary, by gentle heart taking care not to melt it. When soft enough mix thoroughly for determination of moisture and volatile matter. For other determination melts in drying oven at a temperature at least $10^{\circ} \mathrm{C}$ above the $\mathrm{mp}$. If clear proceed directly. If turbid or contains sediment filter test sample inside a oven. For determination in which results might be affected by possible presence of water (eg iodine value) dry sample by adding anhydrous sodium sulphate in the proportion of 1-2 gm per 10 gm sample and hold (keep) it in oven at $50 \mathrm{C}$. Stir vigorously and filter to obtain clear filtrate . To retard rancidity keep oil and fats in cool place and protect from light and air.

\subsection{Blends}

Blends of biodiesel and conventional hydrocarbon-based diesel are products most commonly distributed for use in the retail diesel fuel marketplace. Much of the world uses a system known as the number factor to state the amount of biodiesel in any fuel mix but this project deals with use of oil diesel blendings. Let us consider as B factor: fuel containing $20 \%$ biodiesel is labeled B20, while pure biodiesel is referred to as B100. Blends of 20 percent oil with 80 percent petroleum diesel (B20) can generally be used in unmodified diesel engines. Biodiesel can also be used in its pure form (B100), but may require certain engine modifications to avoid maintenance and performance problems.

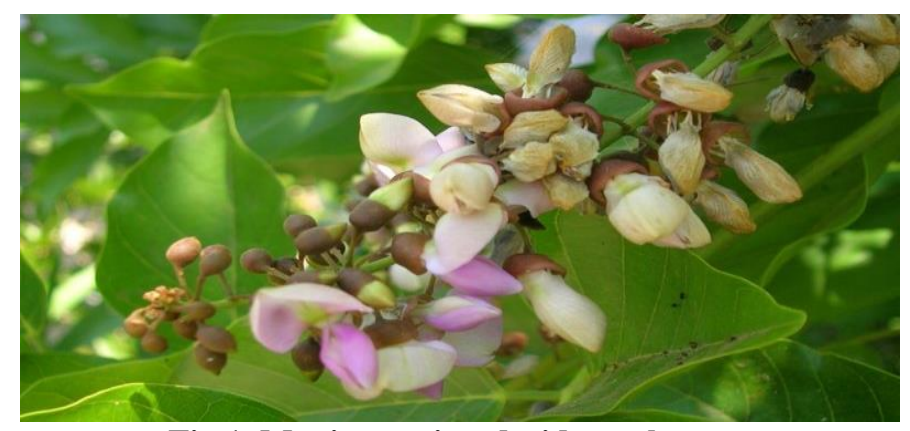

Fig.1. M. pinnata is a deciduous legume 


\section{International Advanced Research Journal in Science, Engineering and Technology}

Vol. 8, Issue 6, June 2021

\section{DOI: $10.17148 /$ IARJSET.2021.8620}

Tree that grows to about 15-25 meters (15-80 ft) in height with a largecanopy which spreads equally wide. The leaves are a soft, shiny burgundy in early summer and mature to a glossy, deep green as the season progresses. Flowering starts in general after 3-4 years. Cropping of pods and single almond sized seeds can occur by 4-6 years. Small clusters of white, purple, and pink flowers blossom on their branches throughout the year, maturing into brown seed pods. The tree is well suited to intense heat and sunlight and its dense network of lateral roots and its thick, long taproot make it droughttolerant. The dense shade it provides slows the evaporation of surface water and its root nodules promote nitrogen fixation, a symbiotic process by which gaseous nitrogen $\left(\mathrm{N}_{2}\right)$ from the air is converted into ammonium $\left(\mathrm{NH}_{4}{ }^{+}\right.$, a form of nitrogen available to the plant). Withstanding temperatures slightly below $0{ }^{\circ} \mathrm{C}\left(32{ }^{\circ} \mathrm{F}\right)$ and up to about $50{ }^{\circ} \mathrm{C}\left(120{ }^{\circ} \mathrm{F}\right)$ and annual rainfall of 500-2,500 mm (20-100 in), the tree grows wild on sandy and rocky soils, including oolitic limestone, but will grow in most soil types, even with its roots in salt water [9-10].

More specifically M. pinnata is an outbreeding diploid legume tree, with a haploid chromosome number of 11 . Root nodules are of the determinate type (as those on soybean and common bean) formed by the causative bacterium Bradyrhizobium.
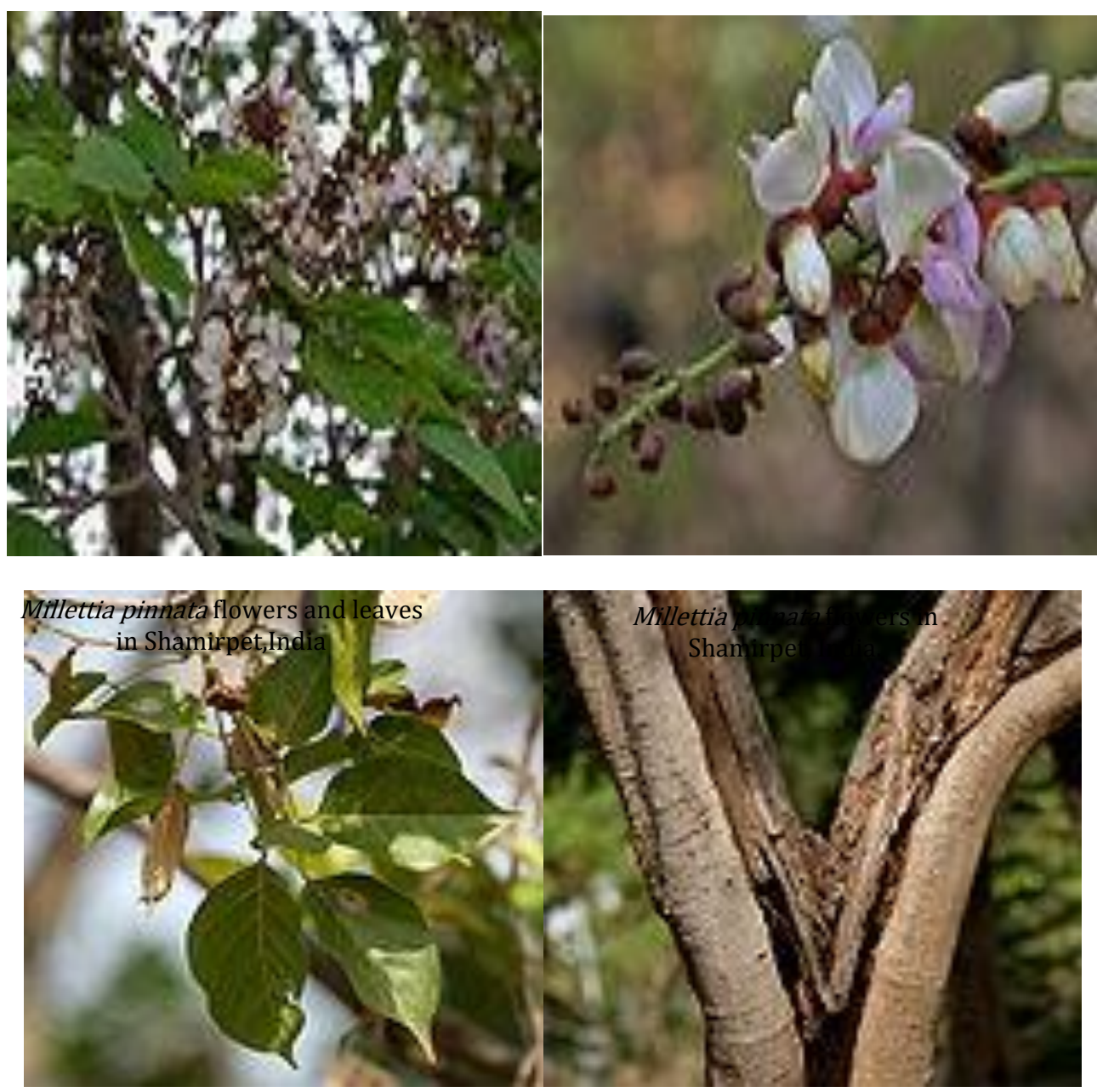

Millettia pinnata leaves in Hvderabad, India.
Millettia pinnata trunk in Hyderabad, India. 
Vol. 8, Issue 6, June 2021

DOI: $10.17148 /$ IARJSET.2021.8620

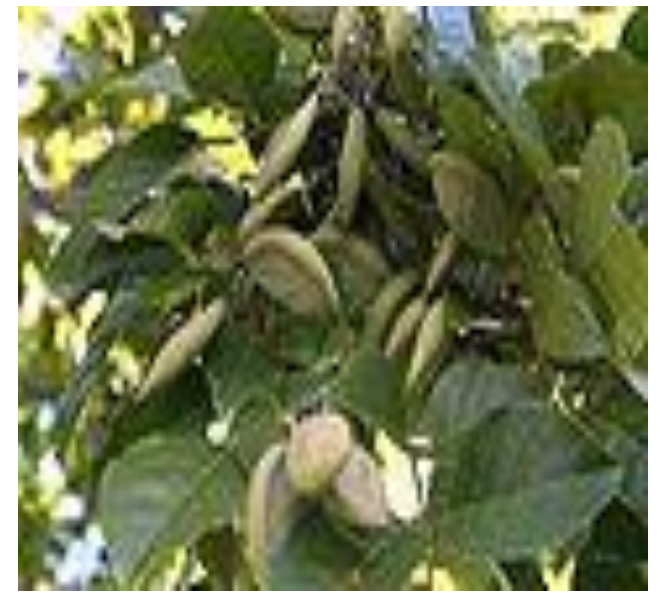

Millettia pinnata seeds in Brisbane, Australia

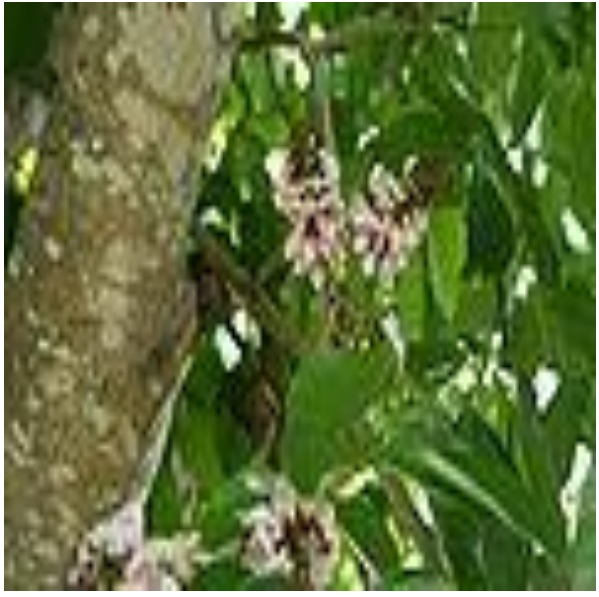

Millettia pinnata flowers in Brisbane, Australia.

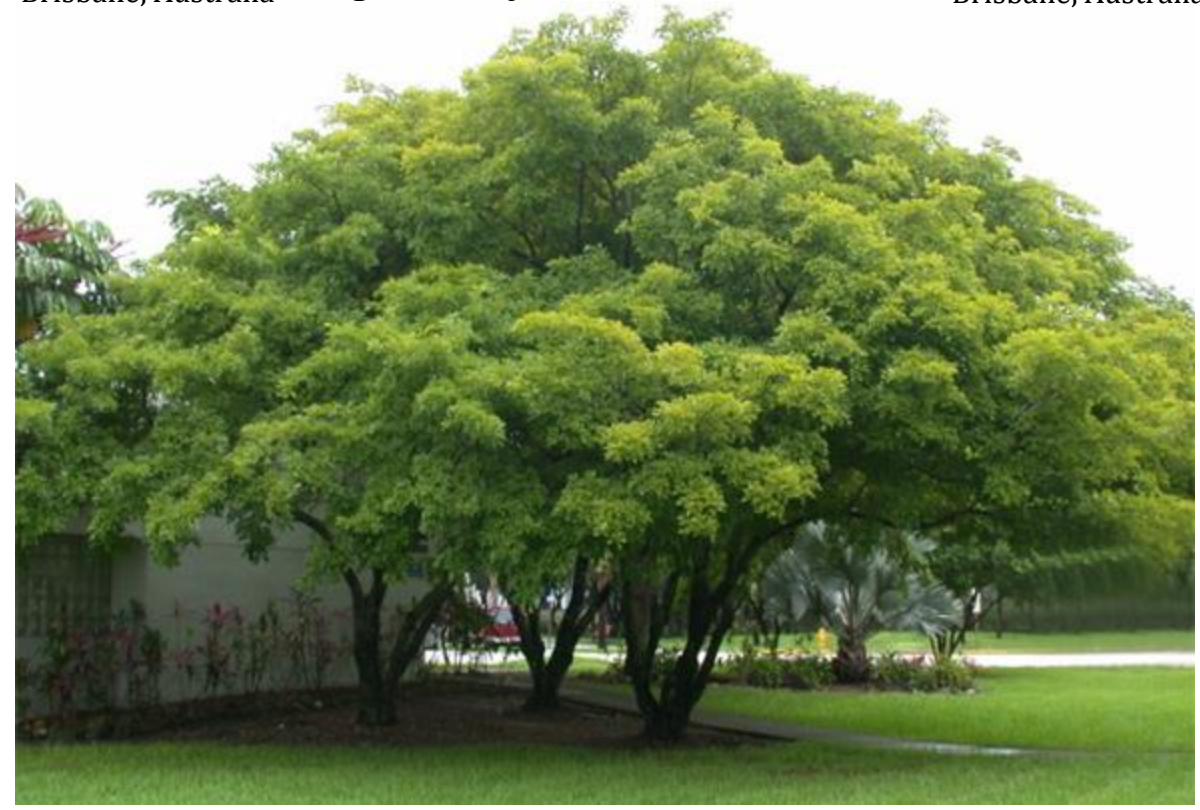

Fig. 3. Honge Tree

\subsection{Honge oil}

Honge oil (or karanja oil) is derived from the Pongamia pinnata, which is native to India. The word honge comes from the Kannada word for this plant. which is highly competitive with other potential fuel oils. Researchers in India have estimated that honge oil could completely replace India's consumption of petroleum based fuels.

Table.1. Honge oil is composed of the following fatty acids.

\begin{tabular}{|l|c|c|}
\hline \multicolumn{1}{|c|}{ Fatty acid } & Nomenclature & Percentage \\
\hline Palmitic & $\mathrm{C} 16: 0$ & $11.6 \%$ \\
\hline Stearic & $\mathrm{C} 18: 0$ & $7.5 \%$ \\
\hline Oleic & $\mathrm{C} 18: 1$ & $51.5 \%$ \\
\hline Linoleic & $\mathrm{C} 18: 2$ & $16.0 \%$ \\
\hline Linolenic & $\mathrm{C} 18: 3$ & $2.6 \%$ \\
\hline Arachidic & $\mathrm{C} 20: 0$ & $1.7 \%$ \\
\hline Eicosenoic & $\mathrm{C} 20: 1$ & $1.1 \%$ \\
\hline Behenic & $\mathrm{C} 22: 0$ & $4.3 \%$ \\
\hline
\end{tabular}




\section{International Advanced Research Journal in Science, Engineering and Technology}

Vol. 8, Issue 6, June 2021

\section{DOI: $10.17148 / I A R J S E T .2021 .8620$}

\section{RESULTS AND DISCUSSION}

Increasing population and uncontrolled urbanization had created serious problems of energy requirement. Demand for transport fuel is increasingly unabatedly in India. On the other hand there are frequent hikes in prices of fossil fuel and uncertain supply in international market, to minimize the import crude oil we must go for which are renewable and ecofriendly.

India was the fourth top net crude oil (including crude oil products) importer of $163 \mathrm{mt}$ in 2015 . India has 4561 million barrels per day $\left(5.7 \%\right.$ of the world) crude oil refinery capacity which is ranked $4^{\text {th }}$ globally. Whereas the domestic production crude oil and natural gas will be less as compared to demand. There is huge gap between demand and supply which is presently met by imports putting heavy burden of foreign exchange on the country. Production of Bio diesel from oil and ethanol from sugar based resources and non edible forestry seeds oils are considered as the best substitute of biodiesel and gasoline respectively in the country. The waste and degraded land after reclamiation can be used to grow the resources, produce oil and its conversion to biodiesel and gasoline respectively in the country. (the biodiesel are mainly ester of long chain fatty acids of vegetable oil or animal fats either from plants or animals). The biodiesel when mixed with diesel up to $20 \%$ requires very little or no modification internal combustion engine and brings substantial production in the emission of unburned hydro carbons by $30 \%$, carbo monoxide $20 \%$ and particulates matters by $25 \%$ with no sulhpur. The diesel has nearly $10 \%$ more oxygen which facilitates the combustion and enhance the cetan number $[11]$.

Just like petroleum-based fuel, biodiesel operates in the $\mathrm{Cl}$ engines. The biodiesel is characterized for its physical and fuel properties, including density, viscosity, cetane number, iodine value, acid value, cloud point and power point, dioill atom of range, flash point, ash content, sulfur content, carbon residue, copper conversion and higher heating values some biodiesel standards are ASTM D 6751 (ASTM = American society for testing and materials) standard identifies the pure biodiesel (B100) must meet before used as a fure fuel of being blended with petroleum based diesel fuel. ASTM standards of maximum allived quanties in diesel and biodiesel. As per the literature survey and investigated fuel properties of biodiesel from non edible oils such as Karanja, Neem and Jatropha shows the fuel properties of non edible oils. The injection and atomization characteristics of the vegetable oils are significantly different than those of petroleum derived diesel fuels, mainly of the 8 results 2 their high viscosities. High viscosity loads to poorer alomization of the fuel spray and less accurate operation of the fuel injectors. The server viscosity of the biodiesel, the easier it is to pump and atomize. The viscosity, the kinetic viscosity in biodiesel is determined using ASTM D6751 [12].

The cetane number is an important parameters for the determination of diesel fuel quality especially the ignition quality. It measures the readiness of the fuel to auto ignite when injected into the engine cetane number of non edible oil and its blends is higher than that petroleum. Therefore they can be replaced for the combustion engine. Another important property of biodiesel fuel is its flash point. Flash point of a fuel is the lowest temperature at which it will spontaneously ignite without the presence of a flame or spark. Non edible have quite high flash point which make them less volatile and safar to transport or handle than diesel fuel. The important parameters for low temperature applications of the fuel are cloud point and pour point. The cloud point is the temperature at which was first becomes visible when the fuel Is cooled the pour point is the temperature at which the amount of was from a solution is sufficient to get the fuel turns it is the lowest temperature at which fuel can flow compared to ASTM D6751 standards for biodiesel fuel, cloud point and pour points of non-edible oils and its blends are similar to Biodiesel fuel. The biodiesel has a higher cloud point and pour point very significantly with stock depending on faty acid comparation.

The density is another important property of biodiesel fuel. It is the mass per unit volume of any liquid at a given temperature specific gravity is the ratio of the density of a liquid to the density of water. Specific gravity of biodiesel and its blends ranges between 0.91 to 0.82 . An increase in density from 0.9388 to 0.841 for the non edible oils and its blends is due to the presence of higher molecular weight of triglycenides. HHV is an important parameters in the selection of fuel. The higher HHV, of biodiesel (0.02 to 0.05 ) are slightly lower than petrodiesel because of their higher content. Ash and ash content or a plant part makes it less desirable as fuel, where are high extractive content adds it its disability [13].

Table. 1. To incorporate along with procedure RFA

The non-edible oils have higher viscosity, specific gravity, flash and fire point.

\begin{tabular}{|l|c|c|c|c|c|c|c|}
\hline \multirow{2}{*}{$\begin{array}{c}\text { ANALYTICAL } \\
\text { DATA }\end{array}$} & Units & \multirow{2}{*}{ KARANJ } & \multirow{2}{*}{ Diesel } & $\begin{array}{c}\text { 100\% } \\
\text { Biodiesel }\end{array}$ & $\begin{array}{c}75 \% \\
\text { Biodiesel }\end{array}$ & $\begin{array}{c}50 \% \\
\text { Biodiesel }\end{array}$ & $\begin{array}{c}20 \% \\
\text { Biodiesel }\end{array}$ \\
\hline Density & $\mathrm{Gm} / \mathrm{cc}$ & 0.9388 & 0.804 & 0.900 & 0.856 & 0.849 & 0.841 \\
\hline Moisture & $\%$ & 0.05 & 0.005 & NA & & & 0.070 \\
\hline $\begin{array}{l}\text { Sediment } \\
\text { insoluble }\end{array}$ & $\mathrm{ppm}$ & 8 & & & & & \\
\hline
\end{tabular}


International Advanced Research Journal in Science, Engineering and Technology

Vol. 8, Issue 6, June 2021

DOI: $10.17148 /$ IARJSET.2021.8620

\begin{tabular}{|c|c|c|c|c|c|c|c|}
\hline Ash & $\%$ & 0.05 & 0.01 & & & & \\
\hline Acid value & $\%$ & 16.8 & 0.35 & & & & \\
\hline $\begin{array}{l}\text { Saponification } \\
\text { value }\end{array}$ & $\mathrm{Mg} / \mathrm{Gm}$ & 185.7 & 183 & & & & \\
\hline Iodine value & $\%$ & 86.5 & 99 & & & & \\
\hline Carbon Residue & $\%$ & 0.8 & 0.17 & 0.530 & & & 0.080 \\
\hline $\begin{array}{l}\text { Copper Strip } \\
\text { Corrossion }\end{array}$ & & $\begin{array}{c}\text { Non } \\
\text { Corrossive } \\
\end{array}$ & $\begin{array}{c}\text { Non } \\
\text { Corrossive }\end{array}$ & $\begin{array}{c}\text { Non } \\
\text { Corrossive }\end{array}$ & $\begin{array}{c}\text { Non } \\
\text { Corrossive } \\
\end{array}$ & $\begin{array}{c}\text { Non } \\
\text { Corrossive } \\
\end{array}$ & $\begin{array}{c}\text { Non } \\
\text { Corrossive }\end{array}$ \\
\hline Boiling Point & $\mathrm{C}$ & 340 & & & & & \\
\hline Cloud Point & $\mathrm{C}$ & 22 & -16 & & & & \\
\hline Calorific value & K.cal/Kg & 34 & 42.5 & 39.17 & 39.86 & 40.14 & 41.32 \\
\hline Flash point & $\mathrm{C}$ & 202 & 64 & 174 & 136 & 108 & 82 \\
\hline Cetane Number & & 52 & 46 & 54.53 & 52.0 & 51.8 & 51.3 \\
\hline Fire Point & $\mathrm{C}$ & 224 & 61 & 134 & & & 72 \\
\hline Freezing Point & $\mathrm{C}$ & -2 & & & & & \\
\hline Pour Point & $\mathrm{C}$ & -4 & -20.0 & 7 & & & 15 \\
\hline Peroxide value & $\mathrm{meq} / 02 / \mathrm{Kg}$ & 18 & & & & & \\
\hline Unsap Matter & $\%$ & 0.90 & & & & & \\
\hline \multicolumn{8}{|l|}{ Refractive Index } \\
\hline $\begin{array}{l}\text { Viscosity at } \\
37.8 \mathrm{C}\end{array}$ & $\mathrm{mm} 2 / \mathrm{S}$ & 27.84 & 3.61 & 5.70 & 4.79 & 4.12 & 4.2 \\
\hline \multicolumn{8}{|l|}{$\begin{array}{l}\text { Carbon } \\
\text { Emmission }\end{array}$} \\
\hline SP Gravity & & 0.899 & 0.84 & 0.99 & 0.88 & 0.86 & 0.84 \\
\hline
\end{tabular}

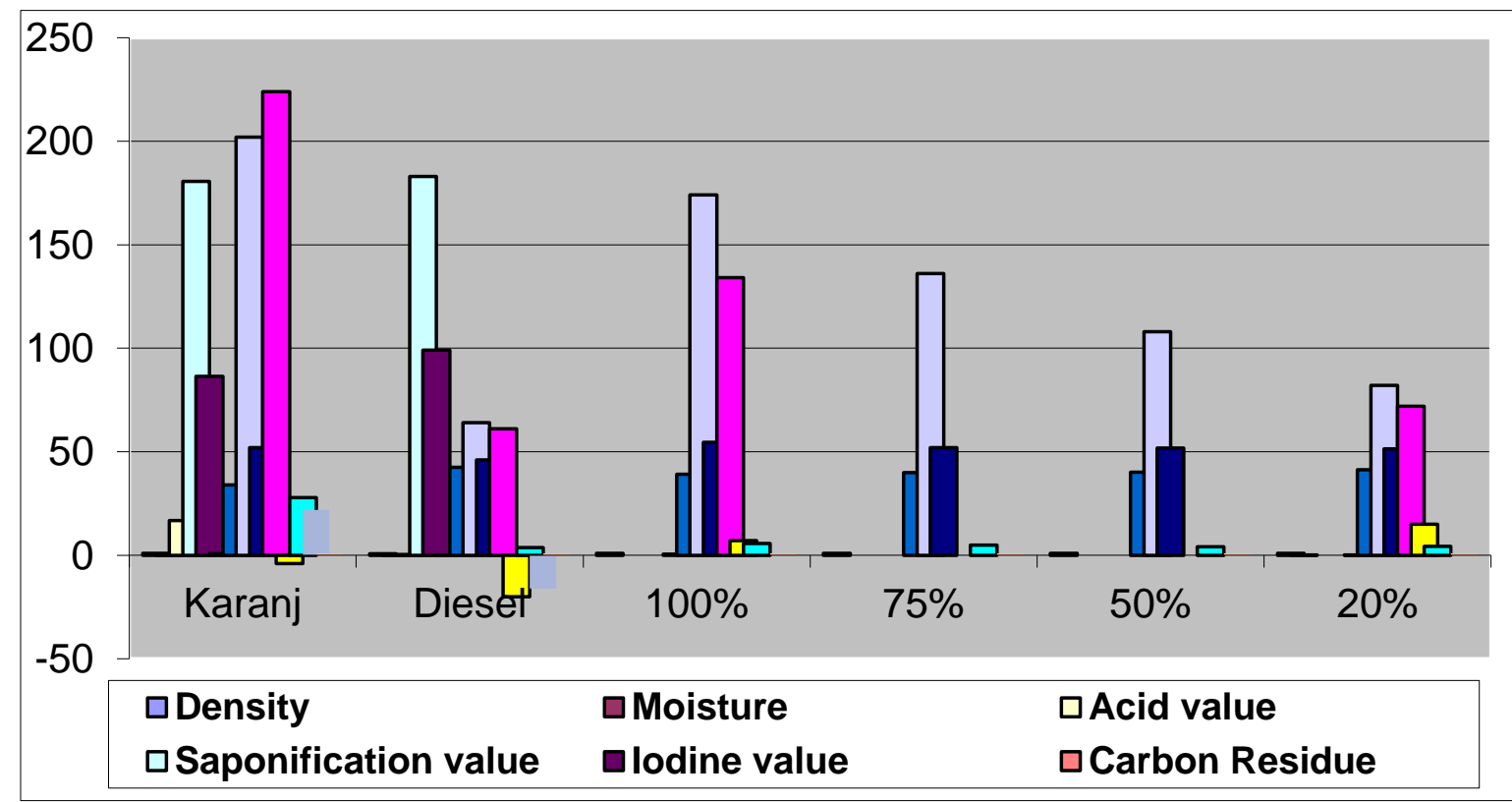

Fig.4. different physic-chemical properties of liquid fuels such as viscosity, density calorific value, flash point, fire point, pour point of diesel, Karanja oil and its blends.

\subsection{Karanja}

Experiments were conduct as per ASTM specified standards and the different physic-chemical properties of liquid fuels such as viscosity, density calorific value, flash point, fire point, pour point of diesel, Karanja oil and its blends, Karanja biodiesel and its blend were measured. Similarly the composition and calorific value of producer gas were obtained using gas chromatography (Bease availability of limited experimental facilities the other properties of 


\section{International Advanced Research Journal in Science, Engineering and Technology}

Vol. 8, Issue 6, June 2021

DOI: $10.17148 /$ IARJSET.2021.8620

producer gas have been collected from the published article). From the above fuel properties it has observed that the fuel samples are suitable as diesel substitute and selected for engine testing. The fuel samples of fossile diesel $20 \%$ Karanja Biodiesel Blend were prepared for test engine. In the performance and emission analysis \% has been found that Karanja Biodiesel blend up to B20 shows better thermal efficiency, lower brake specific fuel consumption lower hydro carbons and carbon monoxide emission. Only the oxides Nitrogen emission observed were more due to more oxygen content and higher combustion temperature of biodiesel blend than diesel. In combustion analysis it was observed that biodiesel shows comparable heat release rate and peak pressure with diesel. From the study which can be concluded that Karanja biodiesel could be the feature potential alternative for diesel engine and blend up to B20 can be used in diesel engine without any major modifications [14].

\subsection{Fuel properties of non-edible forestry seed oil}

Non-edible forestry seed oils are mainly composed of triglycerides that consists of one molecule of glycerol combined with three molecules of fatty acids. The latter contain a long chain of carbon atoms, linked by single bonds and combined with hydrogen, ending with a carboxyl group. Fossil fuel oils are complex mixtures of hydrocarbons which contain paraffins, naphthenes, olefins, and aromatics . The different chemical composition, non-edible forestry seed oils have similar fuel properties to petroleum-derived diesel fuels, so they are suitable for fuelling diesel engines. Oil have several advantages over fuel oil for use as fuel in stationary diesel engines: 1) local availability, 2)renewability, 3)relativity high $\mathrm{HHV}$, 4) a lower sulphur content, avoiding the environmental issues caused by sulphuric acid, 5) a lower aromatic content and 6) high biodegradability [15] .

However, due to the high viscosity of oils and their low cetane number,slight engine adaptations are required and specific operating precautions need to be observed.

\subsection{Kinematic viscosity}

Oil viscosity is much higher than that of diesel fuel: it increases with the carbon chain lengths . triglyceride unsaturation which induces polymerization, and when the temperature decreases. Common SVOs have a kinematic viscosity of $30-40 \mathrm{cSt} \mathrm{t} 40^{\circ} \mathrm{C}$, i.e. 10-15 times higher than that of diesel.

Oil high viscosity causes 1) a decrease in injection rate due to head losses in fuel injection pumps,filters and injectors,2)poor fuel atomization and vaporization by the injectors, which leads to incomplete combustion inside the combustion chamber. This results in lower thermodynamic efficiency, and an increase in soot emissions and particles.

Oil kinematic viscosity does not meet the requirements of diesel fuel standard ASTM D396, which sets a limit value of 2-3.6 cSt and 5.8-26.4 cSt at $38^{\circ} \mathrm{C}$ for grade No.2-D (diesel) and grade No.4-D (medium distillate) respectively. For low- speed stationary engines, manufacturers recommend an optimum kinematic viscosity of between 13 and $17 \mathrm{cSt}$ for fuel before entering the pump. As for heavy fuel, the kinematic viscosity of SVO at rom temperature exceeds the required range, thus needing pre-heating to reduce it $(48,59)$. As shown in figure 4 , for a typical heavy fuel viscosity of $180 \mathrm{cSt}$ at $50^{\circ} \mathrm{C}$, it is necessary to heat the $\mathrm{HFO}$ to between $114^{\circ} \mathrm{C}$ and $125^{\circ} \mathrm{C}$ to reach the appropriate viscosity, while SVOs require only $67^{\circ} \mathrm{C}$ to $78^{\circ} \mathrm{C}$ to achieve the same viscosity [16].

\subsection{Cetane Number}

The cetane number reflects the ability of a fuel to self-ignite when compressed under standardized conditions.It is a direct indicator of the ignition delay of the fuel in the combustion chamber after its injection. The higher it is, the easier the fuel is to ignite (easy cold start).The cetane numbers obtained for most non-edible forestry seed oils are low, between 29 and 43, as opposed to at least 45 for diesel and 40 for DDO, but they are within the range of Fuel-Oil 180 (Table 2).As for diesel, this low cetane number for non-edible forestry seed oils leads to incomplete combustion when the engine is idling,difficult cold starting of the engine and increased engine noise.it is known that the self-ignition delay of fuels decreases as their injection temperature increases .

\subsection{Impurities}

Depending on the quality and cleanness of the biomass used upstream and the extraction and storage conditions, non-edible forestry seed oils can contain impurities that might lead to engine faults or damage when used as fuel. According to most authors, the most harmful impurities for diesel engines are phospholipids, sediments, high free fatty acid contents and water.

Phospholipids come directly from the breakdown of cell membranes within the plant biomass. Their concentration depends on the extraction techniques used, and especially the temperatures reached during cooking treatment and pressing; high temperature conditions cause phospholipids to dissolve in oils. When the oils are used in an engine, the phospholipids polymerize under the effect of heat and are responsible for the formation of deposits that clog injectors and valves, and build up on the combustion chamber walls and cylinder surfaces.

Sediments can be of two kinds, either organic or mineral. In the first case it may involve fragments that come directly from the breakdown of plant tissues, or from particles that are formed via reactions polymerizing free fatty acids, or other 


\section{International Advanced Research Journal in Science, Engineering and Technology}

Vol. 8, Issue 6, June 2021

DOI: $10.17148 / I A R J S E T .2021 .8620$

minority compounds formed during storage. unsuitable storage conditions (presence of air, light, metal tanks, etc)are conductive to the formation of organic sediments. Sediments of mineral origin come from impurities(sand, soil)that have not been totally separated from the biomass prior to extraction. As some sediments dissolve when hot, it is preferable to filter oils cold $\left(<50^{\circ}\right)$, after a possible sedimentation stage enabling separation of the densest sediments by gravity [17].

Although sediments do not cause any real combustion difficulties, they can cause peripheral engine parts,such as filters or pumps, to malfunction. Indeed, sediments may clog the fuel filter and cause cause additional losses in the circuit, leading to a very significant increase in the injection pressure. Mineral sediments, which are the most harmful because they are highly abrasive, damage fuel feed circuits and the inner wall of the combustion chamber .

The acidity of oil is mainly due to the existence of free fatty acids from the hydrolysis of triglycerides in the presence of water. Such hydrolysis reactions may take place fin the biomass if it is stored under poor conditions (moisture),during pressing if the temperatures are too high, and during oil storage in the presence of water and light. Oil acidity is responsible for damage to engine feed circuits (hose, gasket, etc.),engine corrosion and SVO instability during storage.

Water present in oils comes directly from biomass that has been poorly dried, or from condensation under poor oil storage conditions. Water hydrolysis triglycerides to form free fatty acis. The presence of water in non-edible forestry seed oil deteriorates fuel filter cartridges. In addition, during combustion, the existence of water causes cavitations events, articularly at the piston head. which may cause serious damage. n general, the presence of water in a fuel is detrimental, as it lowers the heating value, disrupts ignition and slows down flame propagation [18-19].

\subsection{Vehicle and stationary diesel engines}

Diesel engines are used rather for heavy applications, mainly for transport (road, rail or sea), producing shaft power (agriculture, industry) or electricity generation. They are internal combustion engines with spontaneous ignition of the air/fuel mixture under the combined effect of pressure and temperature. They are designed to run on fossil fuels called fuel oils, such as high distillates(diesel),medium distillates(such as DDO Distillate Diesel oil)or low distillates(such as Fuel Oil 180).Diesel engines are divided into two major categories, vehicle diesel engines used for transport, and stationary diesel engines used for shaft power and/or electricity generation, and in the marine sector.

\subsection{Vehicle diesel engines}

Vehicle diesel engines, used in the transport sector, operate at high speeds (4000-5000 rpm) and are designed to withstand very variable operating conditions (in terms of speed and load) depending on traffic conditions and vehicle weight. this leads to considerable temperature variations in the combustion chamber. Given their low cetane number their combustion may be incomplete and form deposits that foul the engine. Consequently, it seems difficult to fuel a vehicle engine with non-edible forestry seed oil in the long term. It is definitively not recommended with last generation engines (common rail injection).

\subsection{Stationary diesel engines}

Stationary diesel engines are designed to produce shaft power with high efficiency around the rated speed. They are generally used for applications where load variations are limited, which guarantees high combustion temperatures, provided the engine is correctly sized. Unlike vehicle engines, stationary engines operate at slow speeds (900 rpm at the mot for the smallest), with high compression rates. These characteristics provide better combustion conditions, notably longer residence times and higher temperatures, so that fuels with lower cetane numbers can be used. These engines are therefore perfectly suitable for use with fuels such as DDO, Fuel Oil 180 or SVO with lower cetane numbers than diesel.

\section{CONCLUSION}

Karanja Biodiesel V/S Diesel: The engine performance for biodiesel is similar to that of diesel with nearly same thermal efficiency, but with higher fuel consumption due to lower energy contract / calorific value.Biodiesel produced lower co emissions to reduces co emission 20-30\% that diesel fuel all load engine conditions. Also the unburnt hydrocarbons and NOX emissions are reduced. The Study has enabled us to confirm that karanja can be used as a raw material to obtain biodiesel, which can be used as fuel in the diesel engine. The engine performance with biodiesel is similar to that diesel, while emissions ore less in the case of biodiesel. There are two aspects of processing. The cost of raw material (Vegetable oil) accounts to 60-70\% of the cost of biodiesel fuel. Using non edible oil like Karanja oil (in place or vegetable oil) will sincerely improve the economics of the process (Biodiesel production).

\section{REFERENCES}

[1]. Barsic, N. J., and A. L. Humke. 1981. Vegetable oils: diesel fuel supplements? Automotive Engineering 89(4): $37-41$.

[2]. Bartholomew, D. 1981. Non-edible forestry seed oil fuel. J. Am. Oil Chem. Soc. 58(4): 286-288.

[3]. Bettis, B. L., C. L. Peterson, D. L. Auld, D. J. Driscoll, and E. D. Peterson. 1982.

[4]. Fuel characteristics of non-edible forestry seed oil from oilseed crops in the Pacific Northwest. Agronomy Journal, 74(March/April): 335-39. 


\section{International Advanced Research Journal in Science, Engineering and Technology}

Vol. 8, Issue 6, June 2021

DOI: $10.17148 /$ IARJSET.2021.8620

[5]. Bruwer, J. J., B. D. Boshoff, F. J. C. Hugo, L. M. DuPlessis, J. Fuls, C. Hawkins,

[6]. N. VanderWalt, and A. Engelbert. 1981. The Utilization of sunflower seed oil as

[7]. Renewable fuel diesel engines. In Agricultural Energy, Vol. 2, Biomass Energy/Crop

[8]. Production. ASAE Publication 4-81. St. Joseph, MI: ASAE.

[9]. Engelman, H. W., D. A. Guenther, and T. W. Silvis. 1978. Non-edible forestry seed oil as a diesel fuel. Diesel \& Gas Engine Power Division of ASME Paper Number 78-DGP-19.

[10]. Engler, C. R., L. A. Johnson, W. A. Lepori, and C. M. Yarbough. 1983. Effects

[11]. Processing and chemical characteristics of plant oils on performance of an indirect injection.

[12]. Suresh Kumar, GAupta. A.K \& Naik S. N, conversion of non-edible oil into biodiesel, J. Sci and Res, 62 (2003) 124 -132.

[13]. Pramonaik. K. "properties and use of Jarnopha curcus oil and diesel fuel blending in compression ignition engine" Renewable Energy, Vol 28. PP-239, 248, 2003.

[14]. Araniola EF, BetKUE, Ikhuomoregbe DIO, et, al (2014). Production of Biodiesel from nem oil feed stock and its emissions from internal combustion engines. African Journal Biotechnology 11 (22) : $6718-6186$.

[15]. Fatah M. A, Farahitta and ossman ME (2012) production of biodiesel from non-edible oil and effect of blending wish diesel on fuel properties Engineering science and Technology, an international Journal 2(4) : $583-591$

[16]. Misra RD, Murthy MS. Jatropha - The future fuel of India. Renewable and Sustainable Energy Reviews. 2011;15:1350-9.

[17]. Demirbas A. Biodesel from vegetable oils via transesterification in super critical methanol. Energy Conversion \& Mngnt. 2002;43:2349-56.

[18]. Khan LM, Hanna MA. Expression of oil from oilseeds : A review. Journal of Agricultural Engineering Research. 1983;28:495-503.

[19]. Agarwal AK, Rajamanoharan K. Experimental investigations of performance and emissions of Karanja oil and its blends in a single cylinder agricultural. Applied Energy. 2009;86:106-12.

[20]. Agarwal AK, Dhar A Experimental investigations of performance, emission and combustion characteristics of Karanja oil blends fuelled DICI engine. Renewable Energy. 2013;52:283-91.

[21]. Ref:- A.O.A.C $17^{\text {th }}$ edn, 2000. Official method 981.11 oil and Fats-preparation of test sample

[22]. Ref:- A.O.A.C $17^{\text {th }}$ edn, 2000, Official method 920.212 Specific gravity (Apparent) of Oils,Pycnonometer method / I.S.I. Hand book of Food analysis ( Part XIII ) 1984, page 72

[23]. Bacon, D. M., F. Brear, I. D. Moncrieff, and K. L. Walker. 1981. The use of

[24]. vegetable oils in straight and modified form as diesel engine fuels. Beyond the Energy

[25]. Crisis -- Opportunity and Challenge Volume III. Third International Conference on

[26]. Energy Use Management. Berlin (West). Eds. R. A. Fazzolare and C. R. Smith, 1525

[27]. Auld, D. L., B. L. Bettis, and C. L. Peterson. 1982. Production and fuel characteristics of vegetable oilseed crops in the Pacific Northwest Vegetable Oil Fuels: Proceedings of the International Conference on Plant and Vegetable Oils Fuels. 